招請講演抄録 

招請講演 I

\section{iPS細胞と遺伝子改変霊長類を用いた 神経疾患病態解明と創薬研究}

岡野 栄之（慶應義塾大学医学部）

iPS細胞技術は、加齢黄斑変性や春髄損傷などの疾患の再生医療のみならず 医学・医療全般へ応用の側面から注目されている。そのいくつかについて紹介 したい。アルツハイマー病は、認知症の症状が顕著となる30年も前から、生物 学的には発症が始まっており、約 20 年間の無症候期、約10年間の軽度認知障害 （MCI）を経て、認知症としての症状が出現する。無症候期には、急速なべー夕 アミロイドの蓄積と老人斑の形成が起こり、MCIの時期には、既に神経細胞死 や脳の萎縮が始まっている。最終的に介護が必要な機能障害に陥ると様々な治 療症に抵抗性を示すため、無症候期、MCIあるいは超早期の段階で的確に診断 を下し、進行を抑制する薬の開発や発症時期の予測といった先制医療の開発が 急務となる。これまで、発症前のアルツハイマー病の病態研究は、家族性の優 性遺伝を示すアルツハイマー病家系のコフォート研究（DIAN研究）が主体で あったが、侵襲的な解析が不可能なため、分子病態の解明や適切な創薬スクリ —ニング系の開発や認知症に至る神経回路亲ットワークからの解析が同疾患で は進んでいなかった。そこで我々は、この問題に対処すべく、アルッハイマー 病患者由来のiPS細胞を樹立し、病態解析を行い、超早期における治療薬の探索 を行った。試験管内では、患者皮膚線維芽細胞から樹立したiPS細胞由来の神 経細胞は、数週間以内という比較的早期に既に生化学的な異常所見を示し、早 期診断に有効である可能性を示す。また、我々は遺伝子改変技術を用いてアル ツハイマー病原因遺伝子を強制発現するモデルマーモセットの開発に成功して おり、in vivoでのアプローチを計画しており、これらを活用したアルツハイマ 一病の先制医療の開発に着手している。本講演では、昨年より開始されている マーモセットを中心としたBrain Mapping Projectの概要と今後の展望につい て話したい。 


\section{招請講演 I}

\section{岡野 栄之（おかの ひでゆき）}

【勤務先】慶應義塾大学医学部 生理学教室

干 $160-8582$ 東京都新宿区信濃町35

TEL : $03-5363-3747$ FAX : $03-3357-5445$

e-mail : hidokano@a2.keio.jp

\section{【略 歴】}

昭和34年 1 月26日 生まれ

昭和 52 年 4 月 慶應義塾大学医学部入学

昭和58年 3 月 慶應義塾大学医学部卒業

昭和58年 4 月 慶應義塾大学医学部生理学教室（塚田裕三教授）助手

昭和60年 8 月 大阪大学蛋白質研究所 (御子柴克彦教授) 助手

平成元年10月 米国ジョンス・ホプキンス大学医学部生物化学教室（クレイグ・モンテル博士）に留学

平成 3 年 10 月 大阪大学蛋白質研究所（御子柴克彦教授）助手

平成 4 年 4 月 東京大学医科学研究所化学研究部（御子柴克彦教授）助手

平成 6 年 9 月 筑波大学基礎医学系分子神経生物学教授

平成 9 年 4 月 大阪大学医学部神経機能解剖学研究部教授

(平成11年 4 月より大学院重点化に伴い大阪大学大学院医学系研究科教授)

平成13年 4 月 慶應義塾大学医学部生理学教室教授（～現在に至る）

平成19年10月 慶應義塾大学大学院医学研究科委員長

平成20年 オーストラリア・Queensland大学客員教授（～現在に至る）

平成27年 4 月 慶應義塾大学医学部長（～現在に至る)

\section{【主な研究費】}

平成15年 8 月 21 世紀型COEプログラム「幹細胞医学と免疫学の基礎 - 臨床一体型拠点」(医学系、慶應義塾大学) 拠 点リーダー

平成20年 7 月グローバルCOEプログラム「幹細胞医学のための教育研究拠点」

(医学系、慶應義塾大学) 拠点リーダー

平成22年 3 月 内閣府・最先端研究開発支援プログラム（FIRSTプログラム）「心を生み出す神経基盤の遺伝学的解析 の戦略的展開」・中心研究者（〜平成26年 3 月まで）

平成25年 4 月 JST・再生医療実現拠点ネットワークプログラム（拠点A）「iPS細胞由来神経前駆細胞を用いた脊髄損 傷・脳梗塞の再生医療」·拠点長

平成26年 6 月 文部科学省・革新的技術による脳機能ネットワーク全容解明プロジェクト（中核機関・理化学研究所）・ 代表研究者

\section{【資格・学位】}

昭和 58 年 7 月 医師免許（昭和 58 年 5 月医師国家試験合格）

昭和63年 7 月 慶應義塾大学より医学博士

\section{【主たる研究領域】}

·分子神経生物学, 発生生物学, 再生医学

\section{【受賞歴】}

昭和63年＼cjkstart慶應義塾大学医学部同空会・三四会より三四会賞受賞

平成 7 年 加藤淑裕記念事業団より加藤淑裕賞受賞

平成10年 慶應義塾大学医学部より、北里賞受賞

平成13年 ブレインサイエンス振興財団より、塚原仲晃賞受賞

平成16年＼cjkstart東京テクノフォーラム 21 よ、ゴールドメダル賞受賞

平成16年 イタリア・Catania大学より、Distinguished Scientists Award受賞

平成16年 日本医師会より、日本医師会医学賞受賞

平成18年 文部科学大臣表彰・科学技術賞受賞

平成19年 Stem Cells誌よりLead Reviewer Award受賞

平成20年 井上科学振興財団より井上学術賞

平成21年 紫綬敦章受章「神経科学」

平成23年 日本再生医療学会より Johnson \& Johnson Innovation Award受賞

平成25年 Stem Cell Innovator Award受賞（GeneExpression Systems \& Apasani Research Conference USAより）

平成26年＼cjkstart第51回ベルッ賞（1 等賞）受賞 


\section{招請講演 II}

\section{脳の新しい再生様式とPDGFの関与}

笹原 正清 (富山大学 医学薬学研究部 (医学) 病態病理学)

元来、間葉系細胞の増殖因子として同定された血小板由来増殖因子 (PDGF) が脳に豊富に発現し（Cell, 1991）、神経賦活因子として機能することを示した (reviewed in J Neuroimmune Pharmacol, 2014)。本講演では、条件的に同受容 体（PDGFR）遺伝子をノックアウト（KO）した成体マウスを解析した最新の 知見を紹介する。

PDGF-A、Bは脳の広範囲に発現する。PDGFR $\beta$ は神経細胞、脳室下带の神 経幹細胞および血管周囲細胞に主として発現する。生後に同遺伝子を全身で KOしたマウスでは、光凝固により中大脳動脈（MCAO）領域の大脳皮質に誘 導した限局性虚血病変の拡大があり、病変内新生血管への血管周囲細胞の動員 低下による脳血液関門の機能回復が遅延した（J. Cereb. Blood. Flow. Metab., 2012）。FilamentによるMCAOの一過性閉塞により誘導した大脳基底核の虚血 病変では、PDGFR $\beta$ 遺伝子が神経幹細胞と神経細胞でKOされるが血管周囲細 胞では保存されるマウスにおいて虚血巣へのDCX+神経芽細胞の顕著な動員 が見られた（Stem cells, revision）。

PDGFR $\alpha$ はオリゴデンドロサイト前駆細胞（OPC）に特異的に発現し重要 な増殖シグナルを誘導するが、成体脳での役割は不明である。成熟マウスの全 身にPDGFR $a$ 遺伝子のKOを誘導しOPCの細胞動態を調べた。マウスの全身 状態への明らかな影響は見られないが、殆どすべてのOPCが一過性に脳から消 失すると同時に、当該遺伝子のKOを免れた小数の幹細胞が動員されOPCが再 生するという全く新しい細胞動態が明らかになった（未発表）。

これまで知られていない脳に内在する高度の再生能力が明らかとなり、その 制御に二種類のPDGFRがそれぞれ異なった機序で関与した。再生医療への応 用が期待される。 


\section{招請講演 I}

\section{笹原 正清（ささはら まさきよ）}

昭和56年 滋賀医科大学医学部卒業

昭和56年 滋賀医科大学医学部付属病院研修医

昭和57年 滋賀医科大学医学部助手

平成元年 文部省長期在外研究員、米国ワシントン大学

(Russell Ross教授)

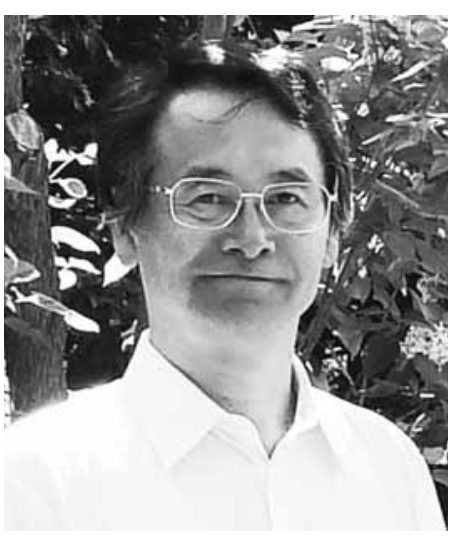

平成11年 富山医科薬科大学医学部病理学第二講座教授

平成17年 富山大学医学部第二病理学講座教授（統合により大学名称変更）

平成25年 富山大学生命科学先端研究センター センター長（兼任）

昭和63年 成人血管病研究奨励賞（岡本賞）（財団法人成人血管病研究振興財団）

平成 9 年 日本病理学会学術研究賞 $\mathrm{A}$ 演説 